\title{
Congenital Malaria
}

\author{
Lt Col RK Thapar*, Col A Saxena ${ }^{+}$, Lt Col A Devgan ${ }^{\#}$
}

MJAFI 2008; 64 : 185-186

Key Words: Congenital malaria; Plasmodium vivax

\section{Introduction}

$\mathrm{C}$ ongenital malaria is defined as malarial parasites demonstrated in the peripheral smear of the newborn from twenty four hours to seven days of life [1]. Clinically apparent congenital malaria is rare in areas in which malaria is endemic and levels of maternal antibody are high. Normally, symptoms occur 10 to 30 days postpartum [2]. The most common clinical features in $80 \%$ of cases are fever, anaemia, and splenomegaly [3]. Other signs and symptoms include hepatomegaly, jaundice, regurgitation, loose stools, and poor feeding. Occasionally, drowsiness, restlessness, and cyanosis may be seen $[1,2]$. Respiratory distress, loose stools and hepatomegaly may also be present [4]. The diagnosis is frequently missed. Those with asymptomatic parasitemia at birth may either suppress this spontaneously, or present with clinical symptoms in the late neonatal period [5].

A preterm neonate born at 34 weeks of gestation presented with respiratory distress requiring continuous positive pressure ventilation. Plasmodium vivax was detected on two occasions in the peripheral blood smear and chloroquine therapy was given to the neonate.

\section{Case Report}

A male neonate was born to a 26 year old gravida three mother by an emergency caesarian, indicated for accidental placental haemorrhage (APH) at 34 weeks of gestation. Neonate required bag and mask ventilation for 30 seconds and weighed 2100 gms. Neonate developed respiratory distress after birth and required continuous positive airway pressure (CPAP) of 4-6cms of water for 54 hours with maximum $\mathrm{FiO}_{2}$ of 0.4 . A clinical diagnosis of transient tachypnoea of newborn (TTNB) was made as skiagram chest was not suggestive of hyaline membrane disease. Neonate developed exaggerated physiological hyperbilirubinemia requiring phototherapy for 24 hours only. Maximum serum bilirubin was $16 \mathrm{mg} / \mathrm{dl}$ at 72 hours of age. Spleen was just palpable. Septic profile, packed cell volume and blood sugar monitoring were normal. However peripheral blood smear showed gametocytes and ring forms of Plasmodium vivax. No evidence of haemolysis was observed on the smear. A repeat smear was also positive. Neonate was treated with chloroquin in doses of $10 \mathrm{mg} / \mathrm{kg}$ stat followed by $5 \mathrm{mg} / \mathrm{kg}$ after 6,24 and 48 hours of the first dose. Neonate was discharged on full breast feeds, without parasitemia after seventh day of diagnosis. Mother denied any history of fever in the antenatal period. Her peripheral smear for malaria parasite was negative. On last follow up at two months of age, neonate weighed $3.75 \mathrm{~kg}$ with normal development and hematocrit.

\section{Discussion}

Congenital malaria is rare with occurrence rate of $0.3 \%$ in immune mothers and $7.4 \%$ in nonimmune mothers [6-8]. In a study of 46 infants, the mean age of onset of symptoms was 5.5 weeks[9]. All these children had fever and majority had hepato-splenomegaly, anemia, and thrombocytopenia. Santhanakrishnan et al [10], reported two cases of congenital malaria diagnosed in the first four months of life in a study of 221 children with malaria. In our case malarial parasite was detected accidentally in the first seven days of life as reported earlier by Kothare et al [11].In another case, a 22day-old neonate presented with history of fever and jaundice for three days before admission, with splenomegaly, anaemia and thrombocytopenia. Gametocytes of Plasmodium vivax were seen in the smear and neonate was treated with chloroquin and primaquin for 14 days [12]. A classic presentation of malaria may not occur in the newborn, since these parasites can only use reticulocytes for replication and these cells are scarce in newborns due to depressed erythropoiesis after birth [7]. Our case had respiratory distress which is not a common finding but has been well documented [4]. The placenta is involved in most women who acquire malaria during pregnancy. It is not clear whether transmission to the infant is transplacental or from direct contact with maternal blood during labour and/or parturition. Most pregnancies resulting in congenital malaria are associated with a malaria attack

${ }^{*}$ Classified Specialist (Paediatrics \& Neonatology), Military Hospital, Meerut Cantt. ${ }^{+}$Senior Advisor (Paediatrics\& Neonatology), ${ }^{\#}$ Classified Specialist (Pediatrics), Base Hospital, Delhi Cantt.

Received : 23.12.2006; Accepted : 31.10.2007_Email:r_thapar@indiatimes.com 
during pregnancy, however congenital infection has been described after uncomplicated asymptomatic pregnancies [13]. The abruptio placenta in our case could have facilitated transmission of parasite.

Chloroquin is the drug of choice for treatment. Primaquin is not required for congenital malaria, because there is no persistent liver phase in congenitally acquired infections. This case highlights the fact that even in endemic regions malaria can afflict the neonates with its varied presentation. Prompt treatment should be instituted to avoid associated morbidity and mortality.

\section{Conflicts of Interest \\ None identified}

\section{References}

1. Arvin AM, Maldonado YA. Protozoan and Helminth Infections. In: JS Remington, JO Klein, editors. Infectious Diseases of the Fetus and Newborn Infant. 4th ed. Philadelphia: WB Saunders, 1995; 765-8.

2. Krause PJ. Malaria (Plasmodium).In: Behrman RE, Keligman R, Jenson HB, editors. Nelson Textbook of Pediatrics. 17th ed. Philadelphia: WB Saunders , 2004; 1139-43.

3. Subramanian D, Moise KJ, White AC. Imported malaria in pregnancy: Report of four cases and review of management. Clin Infect Dis 1992; 15:408.
4. Ibhanescbhor SE. Clinical characteristics of neonatal malaria. J Trop Pediatr 1995; 41: 330-3.

5. Hendrickse RG, Brabin BJ. Paediatrics in the Tropics. In Gordon Cook, editor. Mansion's Tropical Diseases. 20th ed. London: W B Saunders, 1996; 371.

6. Covell G. Congenital malaria. Trop Dis Bull 1950; 1147-67.

7. Akindele J A, Sowunmi A, Abohweyere AE. Congentital malaria in a hyperendemic area: a preliminary study. Ann Trop Paediatr 1993; 13:273-6.

8. Mcgregor IA. Epidemiology, malaria and pregnancy. Am J Trop Med Hyg 1984; 33: 517-25.

9. Hulbert TV. Congenital malaria in the United States: Report of a case and review. Clin Infect Dis 1992; 14: 922-6.

10. Santhanakrishnan BR, Parthasarthy A, Bhawani CR, Ramesh S. Profile of malaria in Madras. Ind J Pediatr 1985; 52:249-52.

11. Kothare SV, Kallapur SG, Irani SF, Prabhu SB, Gangal PS, Agarwal GJ. Congenital malaria (a report of two cases).J Postgrad Med 1987; 33:158-61.

12. Baspinar O, Bayraktaroglu Z, Karsligil T, Bayram A, Coskun Y. A rare case of anemia and thrombocytopenia in a newborn: congenital malaria. The Turkish Journal of Pediatr 2006; 48 : 63-5.

13. Morven S Edwards. Fungal and Protozoal Infections. In:Fanaroff Avroy A, Martin Richard J, editors. Neonatal-Perinatal Medicine: Diseases of the Fetus and Infant. 7th ed. St. Louis: Mosby, 2002; 751-2.

\section{Book Review}

Freakanomics. Steven D Levitt, Stephen J Dubner. PublisherHarper Collins. Pages-206; Price-5.25\$ (Paperback); Paperback \& Hardbound; Date of Publication - May 2005. ISBN Number13 : 978-0-06-114330-4

$\mathrm{T}$ he book authored by Steven D Levitt, a teacher of Economics at the University of Chicago and Stephen J Dubner, an author and journalist "explores the hidden side of everything". The author attacks some of the very basic assumptions we hold about the way people, society, work and most importantly the way we look at data. The book unfolds more like a detective story rather than the typical economic treatise. The author states that the book has been written from a very specific worldview based on a few fundamental ideas; Incentives are the cornerstone of modern life - and understanding them or, often ferreting them out is the key to solving just about any riddle, from violent crimes to sports cheating to online dating. The conventional wisdoms is often wrong. Conventional wisdom is often shoddily formed and devilishly difficult to see through, but it can be done. Dramatic effects often have distant, even subtle causes. The answer to a given riddle is not always in front of us. "Experts" from criminologists to real estate agents use their informational advantage to serve their own agenda.

Knowing what to measure and how to measure it makes a complicated world much less so. If one learns how to look at data in the right way, one can explain riddles that might otherwise seem impossible. And because there is nothing like the sheer power of numbers to scrub away layers of confusion and contradiction.

To give a small example, the author discusses how the crime rate had spurted during the 70 s - 80s attributable mainly to Teenagers and adolescents. Criminologists, political scientists alike forecast the emergence of a new breed of super predators and a massive rise in crime in the United States of America. However despite all such predictions, the crime rate instead of rising, fell by an astounding margin. The author goes on to lay threadbare the various reasons attributed to this fall in crime rate, i.e Better Policing, Improved economy, Stricter gun control laws.

Finally the author states that the judgment on allowing abortion given by US Supreme Court in the Roe vs Wade case, led to a dramatic fall in the number of unwanted and teenage pregnancies and children born out of wed lock. The author states that this judgment leading to the decline in the number of wayward youth was the reason for the decline in the number of crimes.

As mentioned earlier the aim of the book is to "explore the hidden side of everything". Thus the authors have gone about looking at many different scenarios and examine them in a way they have rarely been examined. In some regards this is a strange concept for a book. Most books revolve around a single theme. However there seem to be no single unifying theme in this book. And that is the beauty of the concept behind the book don't accept things at face value. Scrape the surface, analyse the data and wealth of information will unfold in front of you.

\section{Contributed by}

\section{Col S Basu,}

Associate Professor, Department of Hospital Administration, Armed Forces Medical College, Pune. 